\title{
PENGOLAHAN LIMBAH MENJADI MAKANAN RINGAN DI DESA TIKUSAN KECAMATAN KAPAS KABUPATEN BOJONEGORO
}

\author{
${ }^{1)}$ Firda Zakiyatur Rofi'ah ${ }^{2)}$ Wahyu Setia Kuscahyaning Putri, ${ }^{3)}$ Suttrisno \\ ${ }^{13)}$ Program Studi Pendidikan Guru Madrasah Ibtidaiyah, Fakultas Tarbiyah ${ }^{2)}$ Pendidikan \\ Jasmani, Kesehatan, dan Rekreasi, Fakultas Ilmu Pendidikan dan Keguruan \\ *Email: firdazakiyaturrofiah@ymail.com ${ }^{1)}$, wahyu10@unugiri.ac.id ${ }^{2)}, \underline{\text { suttrisno@ unugiri.ac.id }^{3)}}$
}

\begin{abstract}
ABSTRAC
Tikusan Village is one of the villages located ini Kapas District, Bojonegoro Regency. This village has vilaage assets, namely land resources in the form of a home industry (tofu and tempeh industry). ). Therefore, the community assistance method used is the ABCD (Asset Based Community Development) method. The community service program is carried out by a team of lecturers and students of UNUGIRI Bojonegoro in collaboration with the local village community. This assistance produces snack products, such as: debog chips, tofu crackers, sandwiches and corndogs from tofu dregs. The existence of these processed products is expected to be a solution to the presence of abundant assets which are considered as waste, making them less valuable.
\end{abstract}

Keywords; Home Industry, Waste, Snacks

\begin{abstract}
Abstrak
Desa Tikusan merupakan salah satu desa yang berada di Kecamatan Kapas Kabupaten Bojonegoro. Desa ini memiliki aset desa, yaitu sumber daya tanah yang berupa home industry (industri tahu dan tempe). Oleh karena itu, metode pendampingan masyarakat yang digunakan adalah metode ABCD (Asset Based Community Development). Adapun program pengabdian masyarakat ini dilaksanakan oleh tim dosen dan mahasiswa UNUGIRI Bojonegoro yang bekerja sama dengan masyarakat setempat desa. Pendampingan ini menghasilkan produk makanan ringan, seperti: keripik debog, kerupuk tahu, sandwich dan corndog dari ampas tahu. Adanya olahan produk tersebut diharapkan menjadi solusi dari adanya aset berlimpah yang dianggap sebagai limbah, sehingga kurang berharga.
\end{abstract}

Kata kunci; Industri rumahan, limbah, makanan ringan.

\section{PENDAHULUAN}

Penyebaran Covid-19 di Indonesia masih menjadi persoalan besar dari segi perekonomian. Hal ini sangat dirasakan oleh Usaha Mikro Kecil dan Menengah (UMKM) di Desa Tikusan Kecamatan Kapas kabupaten Bojonegoro. Banyak masyarakat Desa Tikusan yang kehilangan pekerjaan dikarenakan tahap pemberhentian hak kerja (PHK), beberapa pabrik gulung tikar, para pedagang kesulitan dalam pemasaran dan kekurangan modal, serta pemberlakuan batasan jam malam. 
Upaya pemerintah dalam memberikan solusi berupa pemberian BLT dampak Covid-19 melalui Kementrian sosial yang disalurkan ke kabupaten, Kecamatan, Desa dan langsung diterima masyarakat yang kurang mampu di tengah pandemi covid-19, dinilai kurang maksimal. Pasalnya jumlah pemberian BLT tersebut sangat terbatas. Apalagi, di Desa Tikusan pembagian BLT dinilai kurang maksimal dikarenakan luasnya wilayah serta padatnya penduduk sehingga hanya masyarakat kelas bawah yang benar-benar membutuhkan dan tidak ada mata pencaharian untuk keberlangsungan hidup.

Pemerintah Desa juga membantu pelaksanaan program prakerja yang dikeluarkan oleh kementrian ketenagakerjaan. Selain itu Pemerintah Desa juga memberi kebijakan agar dana Desa dapat di manfaatkan oleh masyarakat untuk mendorong dan menstabilkan perekonomian sehingga masyarakat bergerak kreatif dan inovatif. Dengan bantuan tersebut masyarakat dapat membuka usahanya kembali atau memberi lapangan pekerjaan padat karya bagi masyarakat Desa Tikusan dalam menjaga kebutuhan dasar selama terdampak covid-19.

Beberapa upaya yang dilakukan pemerintah, nampaknya kurang berimbas pada kondisi ekonomi masyarakat Desa Tikusan. Oleh karena itu, tim KKN UNUGI Bojonegoro berusaha memberikan keterampilan pengolahan makanan ringan dari limbah makanan Desa Tikusan.

Desa Tikusan mempunyai aset home indutry yang banyak, beberapa di antaranya adalah industri tahu dan tempe. Industri tersebut menghasilkan ampas tahu dan tempe yang dianggap sebagai limbah. Selain itu, di desa ini juga terdapat banyak sekali pohon pisang. Debog (pelepah pisang) dari pisang tersebut dianggap belum mempunyai nilai yang berarti sehingga sering dibuang atau dipandang sebagai limbah.

\section{METODE}

Adapun pendekatan yang digunakan dalam pendampingan masyarakat ini adalah metode ABCD (Aset Based Community Development). Metode ini berpusat pada pengembangan masyarakat berdasarkan pada aset lokal yang terdapat di suatu wilayah. Pendekatan ini mempunyai empat siklus, yaitu: Pertama, discovery yaitu kegiatan mengidentifikasi informasi atau pemetaan aset. Adapun beberapa aset yang dimiliki oleh desa Tikusan adalah banyaknya home industry, seperti industri tahu dan tempe. Selain iti, desa ini mempunyai tanaman pohon pisang yang berlimpah. 
Kedua, dream yaitu kegiatan mengetahui aset dan mengidentifikasi peluang. Pada tahap ini, dilakukan pemilahan terhadap beberapa aset yang dimiliki oleh desa Tikusan sekaligus penentuan prioritas program kerja. Adapun prioritas aset yang akan dikembangkan adalah ampas tahu dan debog. Hal ini berdasarkan hasil diskusi tim terhadap masyarakat sekitar, bahwa: aset tersebut dinilai kurang berharga dan dianggap sampah.

Ketiga, design yaitu kegiatan merumuskan strategi. Pada tahap ini, dirumuskan strategi pengolahan makanan ringan, yaitu: kerupuk tahu, keripik debog, sandwich, dan corndog.

Keempat, define yaitu kegiatan merumuskan strategi pendukung keterlaksanaan program kerja. Pada tahap ini, direncanakan kolaborasi terhadap masyarakat setempat yang diawali dengan penyamaan visi misi terkait pembuatan maket edukasi wisata air. Hal ini dilakukan dengan menyelenggarakan pertemuan dengan perwakilan desa Tikusan untuk penyamaan persepsi.

Kelima, destiny yaitu kegiatan mengimplementasikan strategi. Pada tahap ini dilaksanakan proses pengolahan makanan ringan bersama masyrakat setempat.

\section{HASIL DAN PEMBAHASAN}

Pelaksanaan kegiatan pengabdian kepada masyaraat "Pemberdayaan Ekonomi Masyarakat Melalui Kerajinan Rajut Desa Sumberejo Kecamatan Trucuk Kabupaten Bojonegoro.” yang memfokuskan pada kelompok rajut benang pada desa tersebut. Beberapa program yang telah terlaksana diantaranya sosialisasi dan pelatihan pelatihan dan desain rajut berupa tas, gelang, penjepit rambut, konektor masker, dompet. Program yang masih berlangsung saat ini adalah pendampingan kelompok dalam hal memperbaiki kualitas produk dan peningkatan kemampuan kelompok rajut dalam meningkatkan hasil produksi rajut. Selain itu juga saat ini masih dilakukan pendampingan kelompok tentang teknik pemasaran produk-produk hasil produksi mereka.

\section{Pelaksanaan kegiatan}

Desa tikusan kecamatan kapas kabupaten bojonegoro merupakan bagian integral dari sistem perwilayahan kecamatan kapas, desa tikusan terletak di wilayah timur kabupaten Bojonegoro, jarak tempuh ke ibukota kecamatan sejauh 0,5 km dengan lama waktu tempuh 2 menit. Sedangkan jarak tempuh ke ibu kota kabupaten (Bojonegoro) sejauh 2 km dengan jarak tempuh 4 menit.

Kegiatan pengolahan makanan berbahan dasar tahu, ampas tahu dan debog menjadi salah satu program utama yang dilakukan oleh kelompok KKN di Desa Tikusan. Sesuai dengan 
potensi yang di miliki oleh Desa Tikusan mahasiswa KKN mampu mengolah beberapa bahan tersebut menjadi beberapa makanan yang modern dan terkini. Kegiatan ini dilakukan pada tanggal 13 Maret 2021 bersama ibu-ibu PKK Desa Tikusan. Kegiatan pengenalan olahan makanan berbahan dasar tahu dilaksanakan dengan tujuan menambah pengetahuan terkait potensi yang di miliki Desa dan meningkatkan ketrampilan masyarakat dalam hal ekonomi. Jenis olahan makanan berbahan dasar tahu yang di olah menjadi kerupuk dapat memberikan informasi kepada msayarakat bahwa selain menjadi makanan pelengkap tahu juga bisa di olah menjadi variasi lain yaitu makanan ringan.

Selanjutnya, selain kerupuk tahu mahasiswa KKN di Desa Tikusan juga memperkenalkan olahan makanan berbahan dasar pelepah pisang (debog) di hari yang sama pada pertemuan ibu-ibu PKK, dalam hal ini, dengan melihat keadaan yang ada yaitu banyaknya pelepah pisang yang terbuang dan adanya pohon pisang yang dibilang banyak di Desa Tikusan ini mahasiswa KKN berinisatif memanfaatkannya menjadi keripik debog. Selain itu, dihari lain mahasiswa juga memperkenalkan beberapa olahan makanan berbahan dasar ampas tahu yang di olah menjadi sandwich dan corndog. Melihat potensi yang dimiliki oleh Desa Tikusan yaitu beberapa pabrik tahu, dengan alasan lain banyaknya ampas tahu yang terbuang selain yang diolah menjadi tempe, mahasiswa mampu menyulap beberapa olahan makanan berbahan dasar sederhana tahu, ampas tahu dan juga pelepah pisang menjadi makanan yang modern dan terkini.
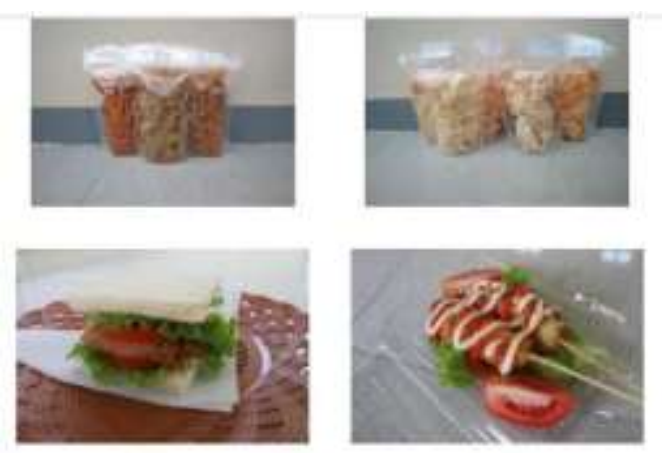

Gambar 1 Produk Makanan Ringan (Keripik Debog, Kerupuk Tahu, Sandwich dan Corndog dari Ampas Tahu)

\section{Evaluasi kegiatan}

Tahapan yang dilaksanakan pada program pengabdian masyarakat dimulai dari tahap persiapan yang terdiri dari tahap (1) persiapan administrasi (2) Koordinasi dengan pihak terkait seperti Kepala Desa, Perangkat dan beberapa pihak lain, (3) Sosialisasi dan pelatihan, (4) Evaluasi kegiatan. 
Evaluasi dilaksanakan dengan pengecekan pemahaman peserta sosialisasi. Kemudian, praktik pengolahan makanan berbahan dasar tahu, ampas tahu dan debog. Selain itu, peneliti membantu mempublikasikan hasil karya desa Tikusan dengan harapan dapat membantu kemandirian masyarakat Desa Tikusan untuk lebih produktif dalam memasarkan produk serta terjadi peningkatan kognitif dan psikomotorik masyarakat terhadap pemasaran olahan makanan berbahan dasar tahu, ampas tahu dan debog.

\section{SIMPULAN}

Kegiatan Penhgabdian Kepada Masyarakat (PKM) di Desa Tikusan Kecamatan Kapas dapat terlaksana dengan baik. Kegiatan dapat diterima oleh masyarakat dan mendapat dukungan oleh seluruh jajaran perangkat desa dan beberapa elemen yang senantiasa antusias dengan kegiatan yang berjalan.

Desa Tikusan memiliki aset desa, yaitu sumber daya tanah yang berupa home industry (industri tahu dan tempe). Aset ini diharapkan mampu menjadi aset Desa Tikusan yang mampu meningkatkan perekonomian masyarakat khususnya Desa Tikusan. Kegiatan pemberdayaan dilakukan dengan pengolahan limbah industri dan debog menjadi makanan ringan. Sosialisasi ini dilakukan kepada masyarakat Desa Tikusan di Balai Desa pada tanggal 13 Maret 2021. 


\section{DAFTAR PUSTAKA}

Buku profil Desa Tikusan Kecematan Kapas Kabupaten Bojonegoro

Arsip Desa Tikusan Kecematan Kapas Kabupaten Bojonegoro

Kemenkopmk.go.id, 07 Agustus 2021 diakses pada Maret 2021

Wawancara Bapak Kepala Desa Tikusan,Ir. Edy sunarto, 04 Maret 2021

Wawancara Ibu Kepala Sekolah TK DW Tikusan, Tutik sulistyowati, S.Pd, 04 Maret 2021

Wawancara Guru SD Tikusan, Suyatmi, S.Pd, 04 Maret 2021

Wawancara Guru TPQ Roudhotul Qur'an, Rukmini, 04 Maret 2021

Wawancara Tokoh Masyarakat, Bapak Mukit, 05 Maret 2021

Wawancara Tokoh Masyarakat,Bapak Wahyu, 05 Maret 2021

Wawancara Tokoh Masyarakat, Bapak Musthofa, 15 Maret 2021 